\title{
Does Export Led Growth Hypothesis Hold Under World Crisis Recovery Regime in Malaysia?
}

\author{
Asmawi Hashim ${ }^{1}$, Norimah Rambeli ${ }^{1}$, Norasibah Abdul Jalil ${ }^{1}$, Normala Zulkifli ${ }^{1}$, Emilda Hashim ${ }^{1}$ \& Noor Al-Huda \\ Abdul Karim ${ }^{1}$ \\ ${ }^{1}$ Faculty of Management and Economics, Universiti Pendidikan Sultan Idris, Malaysia \\ Correspondence: Asmawi Hashim, Faculty of Management and Economics, Universiti Pendidikan Sultan Idris, \\ Malaysia. E-mail: asmawi@fpe.upsi.edu.my
}

Received: October 10, 2019

Accepted: November 5, 2019

Online Published: December 23, 2019

doi:10.5430/rwe.v10n5p9

URL: https://doi.org/10.5430/rwe.v10n5p9

\begin{abstract}
This paper examines empirically the nature of the impact of the exchange rate on import, export and economic growth in Malaysia from 2009 until 2018. The objective of this study is to investigate the long-term and short-term relationship between endogenous and exogenous variables and also to identify the effects of exchange rates on dependent variables including imports, exports and the Gross Domestic Product (DGP) that represent the productivity of the country. This study further focuses on investigating the impact or the role of export in drive the county economic growth. In achieving these objectives, the Augmented Dickey-Fuller (ADF) testing procedure is used to test the presence of unit root. In order to investigate the incidence of long run relationship between the data series, the Johansen Juselius Cointegration Vector is utilized. The Granger Causality in Vector Error Correction Model (VECM) framework is employed to differentiate between short run and long run causal effects in examining the led growth determinants. The result shows that there is causality between exchange rate, import, export and GDP. Moreover, this study shows that exchange rates responded positively to import and export and negatively to GDP. The result further support for export led growth hypothesis in this study. Thus, confirm for the role of export in motivating the economic growth productivity in after World Crisis regime in year 2008. However, Malaysia must not only relay on international trade to generate income for the country. This is because Malaysia is fortunate to have survived the negative effects of the global crisis; the international trade is exposed to exchange rate instability. If Malaysia wants to succeed in international trade, it may be able to focus on food and services trade. As alternative Malaysia may focuses on agriculture sector by improving the research and development and be a champion on food supply for the world.
\end{abstract}

Keywords: exchange rate, import, export, gross domestic product, Vector Error Correction Model

\section{Introduction}

After a decade of the onset of the debt crisis, many countries are still struggling to achieve a current account situation that is in line with reduced external financing and moderate output growth rates leading to higher exchange rates. Exchange rate is an important element for a country because it plays a role in determining international trade flows. Despite some large empirical research, the effect of exchange rate movements on trade flows is still not well understood (Fabus et al., 2019). So, the objective of this study is to investigate the impact of exchange rate on import, export and economic growth in Malaysia. Not only that, the role of international trade in driving the economic growth productivity is also important for short and long term. According to Rambeli and Podivinsky (2013); Wang, Peng \& Lv (2018), The Export-Led Growth Hypothesis (Hereafter: ELGH) can be specified as export expansion is one of the main determinants of economy growth. According to the ELGH, overall growth of countries (in our case is Malaysia) can be generated not only by increasing the amounts of labour and capital within the economy, but also by expanding exports. In recent years, many countries have experienced the value of exchange rate uncertainty, including Malaysia. The exchange rate is, and has always been a very sensitive subject in the WTO (McKinnon, Ronald and Schnabl, 2003; Keho, 2017). This relationship's sensitivity may have more than one source. First, exchange rates are the religious variables derived from complicated macroeconomic, financial shock, economic crisis and global trading trade changes. Second, the exchange rate affects the unsymmetrical real economic costs between different producers and economics (Hussain et al., 2018). Thirdly, Brada and Mendez (1988); Boutayeba (2017) said 
trade in international trade and the result of monetary support supported, and then strengthened the ruler with a lack of history, retaining the opposite nature (Sasongko, Huruta \& Wardani, 2019). There for, the focal point of this study is to investigate the role of export led growth hypothesis under recovery regime of World Crisis in year 2008 for Malaysia experience. To this case, the exchange rates are considered as financial shock shipment lines to real economy and vector 'financial dumping'. Moreover referring to study by Rambeli and Podivinsky (2013), they claimed that the exchange can ruled the productivity of the country, thus give the significant impact through dynamic relationship. Therefore, the impact of changes in nominal and real exchange rates is an important macroeconomic change due to the integration of financial markets and the acceleration of capital flows that lead to instability through two key approaches. Therefore, the purpose of this paper is to study the relationship between exchange rate and import, export and economic growth in Malaysia from 2009 to 2018. The rest of this paper is organized as follows: next section presents model specification. Follow by finding and conclusion in the last part of this article.

\section{Methodology}

\subsection{Model Specification}

As mention before, this study performed the unit root for stationary test. In this case, the Augmented Dickey Fuller test is employed. For integration test, the Johansen Juselius will use. Finnaly the Granger Causality test is conducted under VECM framework. Inspired by Shan, and (1998a) and Rambeli and Podivinsky (2013) the augmented dynamic model for endogenous and exogenous data series are as follows;

\subsection{Dynamic Model}

$$
\begin{aligned}
& \Delta L O G_{-} G D P_{t}=\alpha_{10}+\sum_{i=1}^{n} \alpha_{1 i} L O G_{-} \Delta E R_{t-i}+\sum_{t=1}^{n} \beta_{1 i} \Delta L O G_{-} I M P_{t}+\sum_{i=1}^{n} \phi_{1 i} \Delta L O G_{-} E X_{t-i} \\
& +\sum_{i=1}^{n} \gamma_{1 i} \Delta L O G_{-} G D P_{t-i}+\delta_{1} E C T_{(t-1)}+\Omega_{1 t}
\end{aligned}
$$

\subsection{Data Sources}

This study uses quarterly time series data covering the period from 1987 to 2017. Exchange rate, import, export and GDP data have been extracted from various sources. For exchange rate data, researchers obtain data from the official trading website. Researchers obtain import and export data from FRED's website. Meanwhile for GDP data, researchers obtain from the World Bank.

\section{Finding}

In this section will be described in detail related to the results of the analysis of the study. The description will start with the results from Unit root, co-integration and VECM.

\subsection{Unit Root Test (ADF)}

The result of the ADF unit root tests, the three at the level and at first differencing are reported in Tables 1, by taking into consideration with pure random walk (none), random walk with drift/intercept and random walk with drift and time trend.

Table 1. The result of Augmented Dickey Fuller Tests for exchange rate, import, export and economic growth

\begin{tabular}{lllllll}
\hline Data Series & \multicolumn{2}{l}{ At Level Form } & \multicolumn{3}{l}{ At $1^{\text {st }}$ Different } \\
\cline { 2 - 6 } & none & intercept & time trend & none & intercept & time trend \\
\hline $\begin{array}{l}\text { Exchange } \\
\text { Rate }\end{array}$ & 0.533361 & -1.744273 & -2.364977 & $-7.532907 *(12)$ & $-7.570324 *(12)$ & $-7.533565 *(12)$ \\
\hline Import & 1.200734 & -2.411290 & -1.939224 & $-8.336284 *(12)$ & $-7.533273 *(12)$ & $-7.737034^{*}(12)$ \\
\hline Export & 1.025634 & -1.587791 & -2.432969 & $-8.591001 *(2)$ & $-8.837251^{*}(2)$ & $-9.583527 *(2)$ \\
\hline $\begin{array}{l}\text { Economic } \\
\text { Growth }\end{array}$ & 0.695150 & -1.658039 & -1.725207 & $-4.833341^{*}(3)$ & $-5.952177 *(3)$ & $-6.104689^{*}(3)$ \\
\hline
\end{tabular}

Notes: Figures in parentheses are the lag order selected based on the AIC where '*' indicates significant at the $99 \%$ level 
According to the Table 1, the results show that at level form with pure random walk (none), the result for exchange rate, import, economic growth and export are non-stationary. This means that all variable at pure random walk (none) is insignificant. This result supported by the value of Wald Test less than $\mathrm{F}$ critical value. However, at first different, the result is stationary and significant at $99 \%$ for all four variables. The same results are same for intercept and time trend at level form across the series. Meanwhile, at 1st different, the results show these variables are stationary and significant at $99 \%$ for all types of unit root analysis. In order to get the optimal lag, VAR is utilized. The result of VAR for exchange rate, import, export and GDP are reported in Table 2 in Appendix. The information criteria approach is applied in this study as a direction to choose the lag order. Table 2 confirms the lag lengths selected by different information criteria. The result reveals the results of each lag starting lag 2 until lag 12. It is presented with its Akaike Information Criterion (AIC) value as the general selection would have been done. However, we will be using the AIC value for the optimum lag length selection. Table 2 also shows the optimum lag length is lag 5 with AIC -8.961775. However, in order to perform the VECM test, we will be using lag 10 minus lag 1 . So, lag 4 will choose to do the VECM. (Vahid and Engle, 1993; Lai, 2018)

\subsection{Johansen Juselius Cointegration Test and VECM}

The prerequisites for a series of combined combinations are that they need to be integrated in the same order. So far, the results of the unit testing process are I (1), now we can continue the cointegration test.

Table 3. The results of Johansen Cointegration Tests for exchange rate, import, export and economic growth

\begin{tabular}{|c|c|c|c|c|c|c|c|}
\hline \multicolumn{8}{|c|}{$\begin{array}{l}\text { Data Period: Jan, } \\
1987 \text { to Dec, } 2017\end{array}$} \\
\hline \multicolumn{2}{|c|}{ Hypothesis } & \multirow[b]{2}{*}{$\lambda$ Trace } & \multirow{2}{*}{$\begin{array}{l}5 \% \text { critical } \\
\text { value }\end{array}$} & \multirow{2}{*}{$\begin{array}{l}1 \% \text { critical } \\
\text { value }\end{array}$} & \multirow[b]{2}{*}{$\lambda \operatorname{Max}$} & \multirow{2}{*}{$\begin{array}{l}5 \% \text { critical } \\
\text { value }\end{array}$} & \multirow{2}{*}{$\begin{array}{l}1 \% \text { critical } \\
\text { value }\end{array}$} \\
\hline H0 & H1 & & & & & & \\
\hline$r=0$ & $r>0$ & $48.89499 *$ & 47.21 & 54.46 & 24.91666 & 27.07 & 32.24 \\
\hline $\mathrm{r} \leq 1$ & $r>1$ & 23.97833 & 29.68 & 35.65 & 18.47406 & 20.97 & 25.52 \\
\hline $\mathrm{r} \leq 2$ & $r>2$ & 5.504269 & 15.41 & 20.04 & 5.321876 & 14.07 & 18.63 \\
\hline$r \leq 3$ & $r \leq 3$ & 0.182393 & 3.76 & 6.65 & 0.182393 & 3.76 & 6.65 \\
\hline
\end{tabular}

The critical values for the Johansen Juselius test were obtained from (Osterwald-Lenum, 1992)

Table present the results of the cointegrating test, the statistical test results show that the null hypothesis $r=0$ against the alternative is $r>1$, which is easily rejected at the 0.01 and 0.05 levels significantly. The calculated value 48.89499 is greater than the critical value of 0.05 which is 47.21 and 0.01 at 54.46 . However, if tested the null hypothesis $r \leq 1$, it receives the hypothesis because the calculation value at 23.97833 is smaller than the critical value at 0.05 and 0.01 significant levels, which are 29.68 and 35.65. Therefore, based on trace statistical test, it can be concluded that there exists a single cointegrating vector in the model. This study proposes similar results for Lambda Trace and Lambda Max. These results indicate that the exchange rate and macroeconomic determinants show long-term relationships in one convergence. This means the series in the system move together and cannot move away from each other. Table 4 in Appendix shows the error correction term (ECT) equation. The detection of a cointegration equation in the previous section means that a VECM can be performed. This analysis is important in identifying long-term and short-term relationships between variables. The table 7 shows the result of F-statistic and probability (in bracket). There are some are not available (-) from the table. This because researcher does not want to measure the relationship between the endogenous and exogenous variable itself, rather than researcher wishes to determine the short run relationship between the independent variables with the other the dependent variables.

Table 5. The result of Vector Error Correction Model (VECM) for exchange rate, import, export and economic growth

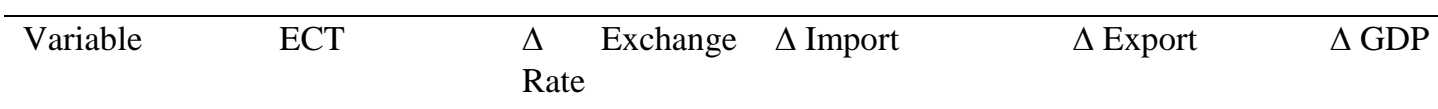




\begin{tabular}{|c|c|c|c|c|c|}
\hline $\begin{array}{ll}\Delta & \text { Exchage } \\
\text { Rate } & \end{array}$ & $\begin{array}{l}-0.006642 \\
(0.1049)\end{array}$ & - & $\begin{array}{l}1.078507 \\
(0.3616)\end{array}$ & $\begin{array}{l}2.307767 \\
(0.1045)\end{array}$ & $\begin{array}{l}5.766538 \\
(0.0003) * * *\end{array}$ \\
\hline$\Delta$ Import & $\begin{array}{l}-0.028681 \\
(0.1498)\end{array}$ & $\begin{array}{l}2.514206 \\
(0.0622)^{*}\end{array}$ & - & $\begin{array}{l}1.485101 \\
(0.1404)\end{array}$ & $\begin{array}{l}-1.438082 \\
(0.1533)\end{array}$ \\
\hline$\Delta$ Export & $\begin{array}{l}-0.013031 \\
(0.0002)^{* * * *}\end{array}$ & $\begin{array}{l}6.412822 \\
(0.0023) * *\end{array}$ & $\begin{array}{l}2.537532 \\
(0.0442)^{*}\end{array}$ & - & $\begin{array}{l}1.564672 \\
(0.2139)\end{array}$ \\
\hline$\Delta \mathrm{GDP}$ & $\begin{array}{l}0.000736 \\
(0.6596)\end{array}$ & $\begin{array}{l}-7.257939 \\
(0.0000)^{* * *}\end{array}$ & $1.711747(0.1528)$ & $\begin{array}{l}3.267244 \\
(0.0421)^{*}\end{array}$ & - \\
\hline
\end{tabular}

According to Table 5, it shows the series of variables effect each one to another in the short term. The results suggest that, during the post regime of world crisis, the export impact economic growth positively. This indirectly support for Export-led Growth Hypothesis for Malaysia case.

\section{Conclusion}

In overall, it is can conclude that the bi-directional and unidirectional causality between variables in Malaysia. The result also support for the role of Export in driving the economic growth in the short and long term. However, Malaysia must not only relay on international trade to generate income for the country. This is because Malaysia is fortunate to have survived the negative effects of the global crisis; the international trade is exposed to exchange rate instability. If Malaysia wants to succeed in international trade, it may be able to focus on food and services trade. The alternative choice for Malaysia is maybe back to agriculture sector by improving the research and development in agriculture and be a champion on food supply for the world.

\section{References}

Afxentiou, P.C., \& Serletis, A. (1991). Exports and GNP Causality in the Industrial Countries: 1950-1985. Kyklos, 44(2), 167-179.

Aghion, Ph., Bacchetta, Ph., Ranciere, R., \& Rogoff, K. (2006). Exchange rate Volatility and Productivity Growth: The Role of Financial Development. Seminar paper: PompeuFabra, PSE, Lausanne, and Zurich.

Ahmad, J. (2001). Causality between Exports and Economic Growth: What do the Econometrics Studies Tell Us?. Pacific Economic Review, 6(1), 147-167.

Ahmad, J., \& Harnhirun, S. (1992). The Causality between Export and Economic Growth in the ASEAN countries: Cointegration and Error Correction Model Approach. Concordia University, Department of Economics working paper DP 9212, Montreal, Canada.

Ahmad, J., \& Kwan, A.C.C. (1991). Causality between Exports and Economic Growth: Empirical Evidence from Africa. Economics Letters, 37, 243-248.

Ahmad, J., Harnhirun, S., \& Yang, J. (1997). Exports and Economic Growth in the ASEAN Countries: Cointegration and Causality Tests. RivistaInternazionale Di ScienzeEconomiche E Commerciali, XLIV, 419-430.

Aizenman, J. (1994). Monetary and real shock, productivity capacity and exchange rate regimes. Economica, 61(244), 407-434.

Akaike, H. (1969). Fitting Autoregression for Prediction. Journal of the Institute of Statistical Mathematics, 21, 203-217.

Akaike, H. (1974). A New Look at the Statistical Model Specification. IEEE Transactions on Automatic Control AC-19, 716-723.

Al-Yousif, Y. K. (1997). Exports and Economic Growth: Some Empirical Evidence from the Arab Gulf Countries. Applied Economics, 29(6), 693-697.

Al-Yousif, Y. K. (1999). On the Role of Exports in the Economic Growth of Malaysia: A Multivariate Analysis. International Economic Journal, 13, 67-75.

Amirkhalkhali, S., \& Dar, A.A. (1995). A Varying-coefficients Model of Export Expension, Factor Accumulation and Economic Growth: Evidence from Cross-Country, Time Series Data. Economic Modelling, 12(4), 435-441.

Arnade, C., \& Vasavada, U. (1995). Causality between Productivity and Exports in Agriculture: Evidence from Asia and Latin America. Journal of Agricultural Economics, 46, 174-186. 
Asafu-Adjaye, J., \& Chakraborty, D. (1999, June). Export led growth and import compression: Further time series evidence from LDCs. Australian Economic Papers, 164-175.

Awokuse, T.O. (2004). In The Export-led Growth Hypothesis Valid for Canada?. Canadian Journal of Economics, $36,126-136$.

Baharumshah, A.Z., \& Rashid, S. (1999). Exports, Imports, and Economic Growth in Malaysia: Empirical Evidence Based on Multivariate Time Series. Asian Economic Journal, 13(4), 389-407.

Bahmani-Oskooee, M. (1991). Is there a long-run relation between the trade balance and real effective exchange rate of LDCs?. Economic Letters, 36, 403-407.

Bahmani-Oskooee, M., \& Alse, J. (1993). Export Growth and Economic Growth: An Application of Cointegration and Error Correction Modelling. Journal of Developing Areas, 27(4), 535-542.

Balassa, B. (1978). Exports and Economic Growth: Further Evidence. Journal of Development Economics, 5(2), 181-189.

Balassa, B. (1985). Exports, policy choices, and economic growth in developing countries after the 1973 oil shock. Journal of Development Economics, 18, 23-35.

Begum, S., \& Shamsuddin, A.F.M. (1998). Exports and Economic Growth in Bangladesh. Journal of Development Studies, 35(1), 89-114.

Bera, A., \& Jarque, C. (1981). Efficient tests for normality, heteroskedasticity and serial independence of regression residuals: Monte Carlo evidence. Economics Letter, 7, 313-318.

Biswal, B., \& Dhawan, U. (1998). Export-led Growth Hypothesis: Cointegration and causality Analysis for Taiwan. Applied Economic Letters, 5, 699-701.

Boutayeba, F. (2017). Estimating the Returns to Education in Algeria. Asian Journal of Economic Modelling, 5(2), $147-153$.

Brada, J.C., \& Mendez, J.A. (1988). Exchange Rate Risk, Exchange Rate Regime and the Volume of International Trade. Kyklos, 41(2), 263-280.

Breusch, T.S. (1979). Testing for Autocorrelation in Dynamic Linear Models. Australian Economic Papers, 17, 334-355.

Breusch, T.S., \& Pagan, A.R. (1979). Simple test for heteroscedasticity and random coefficient variation. Econometrica (The Econometric Society), 47(5), 1287-1294.

Broda, C. (2001). Coping with terms of trade shocks: pegs versus floats. American Economic Review. Paper proceeding, 91(2), 376-381.

Bunda, I., \& Deaquilbet, J. B. (2008). The bank liquidity smile across exchange rate regimes. International Economic Journal, 22(3), 361-386.

Burney, N.A. (1996). Exports and Economic Growth: Evidence from Cross-country Analysis. Applied Economic Letter, 3(6), 369-373.

Chan, S., Clark, C., \& Davis, D.R. (1990). State Entrepreneurship Foreign Investment Export Expansion and Economic Growth: Granger Causality in Taiwan's Development. Journal of Conflict Resolution, 34(1), 102-109.

Charette, D. E. (2006). Malaysia in the Global Economy: Crisis, Recovery, and the Road Ahead. New England Journal of Public Policy.

Chee, W.H., Hui, B.T., \& Annuar, M.N. (2004). Risk Sensitivity of Bank Stock in Malaysia: Empirical Evidence across the Asian Financial Crisis. Asian Economic Journal, 18(3), 261-276.

Choong, C.K., Yusop, Z., \& Khim-Sen, V.S. (2003). Export-Led Growth Hypothesis in Malaysia: An Application of Two-Stage Least Square Technique. New Economics Paper: International Finance, No. 0308002.

Chow, P.C.Y. (1989). Causality between Export Growth and Industrial Development: Empirical Evidence from the NICs. Journal of Development Economics, 26(1), 55-63.

Colombatto, E. (1990). An Analysis of Exports and Growth. Kyklos, 43(4), 579-597. 
Darrat, A. F., Hsu, M. K., \& Zhong, M. (2000). Testing Export Exogeneity in Taiwan: Further Evidence. Applied Economics Letters, 7, 563-567.

Darrat, A.F. (1987). Are Exports an Engine of Growth? Another look at the Evidence. Applied Economics, 19(2), 277-283.

Demirguc-Kunt, A., \& Levine, R. (2008). Finance, Financial Sector Policies, and Long-Run Growth. Commission on Growth and Development, 11.

Dickey, D. A. (1976). Estimation and Hypothesis Testing for Non-stationary Time Series. Unpublished Ph. D. Dissertation, Iowa State University, Ames, IW.

Dickey, D.A., \& Fuller, D.A. (1979). Distributions of the Estimators for Autoregressive Time Series with a Unit Roots. Journal of American Statistical Association, 74, 427-431.

Dodaro, S. (1993). Exports and Growth: A Reconsideration of Causality. Journal of Developing Areas, 27, 227-244.

Domac, I., Peters, K., \& Yuzefovich, Y. (2004a). Does the Exchange Rate Regime Matter for Inflation? Evidence from Transition Economics. Policy Research Working Paper, 1-29.

Domac, I., Peters, K., \& Yuzefovich, Y. (2004b). Does the Exchange Rate Regime Affect Macroeconomic Performance? Evidence from Transition Economics. Policy Research Working Paper, 1-76.

Doraisami, A. (1996). Export Growth and Economics Growth: A Re-examination of Some Time Series Evidence of Malaysian Experience. Journal of Developing Area, 30, 233-240.

Dutt, S.D., \& Ghosh, D. (1994). An Empirical Investigation of the Export Growth- Economic Growth Relationship. Applied Economics Letters, 1, 44-48.

Dutt, S.D., \& Ghosh, D. (1996). The Export Growth-Economic Growth Nexus: a causality analysis. Journal of Developing Area, 30(2), 167-181.

Emery, R.F. (1967). The Relation of Exports and Economic Growth. Kyklos, 20(2), 470-486.

Engle, R. F., \& Granger, C. W. J. G. (1987). Cointegration and Error Correction: representation, estimation, and testing. Econometrica, 5, 251-276.

Fabus, M., Dubrovina, N., Guryanova, L., Chernova, N., \& Zyma, O. (2019). Strengthening financial decentralization: driver or risk factor for sustainable socio-economic development of territories. Entrepreneurship and Sustainability Issues, 7(2), 875-890.

Fajana, O. (1979). Trade and Growth: The Nigerian Experience. World Development, 7(1), 73-78.

Feder, G. (1983). On Exports and Economic Growth. Journal of Development Economics, 12(2), 59-73.

Fuso, A.K. (1990). Exports and Economics Growth: The African case. World Development, 18, 831-835.

Fuso, A.K. (1996). Primary Exports and Economic Growth in Developing Countries. World Economy, 19, 465-475.

Gandolfo, G. (1981). Qualitative Analysis and Econometric Estimation of Continuous Time Dynamic Models. Amsterdam: North-Holland.

Ghartey, E.E. (1993). Causal Relationship between Exports and Economic Growth: Some Empirical Evidence in Taiwan, Japan and the US. Applied Economics, 25(9), 1145-1152.

Ghosh, A.R., Ostry, J.D., Gulde, A.M., \& Wolf, H.C. (1997). Does the Exchange Rate Regime Matter for Inflation and Growth?. IMF Economic Issue, 2, 1-19.

Ghosh, A.R., Ostry, J.D., Gulde, A.M., \& Wolf, H.C. (1997b). Does the norminal exchange rate metter?.National Bureau of Economic Research (Cambridge, MA). Working Paper No. 5874.

Giles, D.E.A., Giles, J.A., \& McCann, E. (1992). Causality, Unit Roots, Export-led Growth: The New Zealand Experience. Journal of International Trade and Economic Development, 1, 195-218.

Godfrey, L.G. (1978). Testing Against General Autoregressive and Moving Average Error Models when the Regressors Include Lagged Dependent Variables. Econometrica, 46, 1293-1302.

Godfrey, L.G. (1988). Misspecification tests in econometrics. Cambridge, UK: Cambridge.

Godfrey, L.G. (1996). Misspecification tests and their uses in econometrics. Journal of Statistical Planning and Inference, 49(2), (Econometric Methodology, Part II), 241-26. 
Gordon, D.V., \& Sayki-Bekoe, K. (1993). Testing the Export-Growth Hypothesis: Some Parametric and Non-Parametric Results for Ghana. Applied Economics, 25, 553-563.

Granger, C. W. J. (1969). Investigating causal relations by econometric models and cross spectral methods. Econometrica, 40, 424-438.

Granger, C. W. J. (1986). Developments in the study of cointegrated economic variables. Oxford Bulletin of Economics and Statistics, 48, 213-228.

Granger, C.W.J. (1988). Some Recent Developments in a Cobcept of Causality. Journal of Econometrics, 39, 199-211.

Greenway, D., \& Sapsford, D. (1994). What does Liberalisation do for Exports and Growth. WeltwirtschafflichesArchiv, 130(1), 152-174.

Gujarati, D. (1995). Basic Econometrics (3rd ed.). McGraw-Hill, New York.

Habibullah, M.S., \& Kee, E.Y. (2006). Does Financial Development Cause Economic Growth? A Panel Data Dynamic Analysis for the Asian Developing Countries. Journal of the Pacific Economy, 11(4), 377-393.

Hanaysha, J. (2016). Testing the effects of food quality, price fairness, and physical environment on customer satisfaction in fast food restaurant industry. Journal of Asian Business Strategy, 6(2), 31-40.

Heller, P.S., \& Porter, R.C. (1978). Export and Growth: An Empirical re-investigation. Journal of Development Economics, 5(2), 191-193.

Henriques, I., \& Sadorsky, P. (1996). Export-led Growth-driven Exports? The Canadian case. Canadian Journal of Economics, 29(3), 541-555.

Henry, D. (1986). Econometrics modelling with cointegrated variables. Oxford Bulletin of Economics and Statistics, 48.

Hooi, T.S., Habibullah, M.S., \& Baharumshah, A.Z. (2008). On Engine of Growth in Malaysia: Export-Led, Financial-Led or Investment-Led?. International Journal of Business and Society.

Hooi, T.S., Habibullah, M.S., Azali, M., \& Baharumshah, A. Z. (2007). Testing for Financial-Led, Export-Led and Import-Led Growth Hypothesis on Four Asian Emerging Economies. International Journal of Economics and Management, 1(3), 307-335.

Hussain, H.I., Abidin, I.S.Z., Ali, A., \& Kamarudin, F. (2018). Debt Maturity and Family Related Directors: Evidence from a Developing Market. Polish Journal of Management Studies, 18(2), 118-134.

Ibrahim, M. (2002). An Empirical Note on the Export-Led Growth Hypothesis: The Case of Malaysia. Economic Analysis and Policy, 32(2), 221-232.

Islam, M.N. (1998). Exports Expansion and Economic Growth: Testing for Cointegration and Causality. Applied Economics, 30(3), 4154-425.

Jin, J.C. (1995). Export-led Growth and the Four Little Dragons. Journal of International Trade and Economic Development, 4(2), 203-425.

Jin, J.C., \& Yu, E.S.H. (1995). The causal Relationship between Exports and Growth. Journal of Economic Development, 20, 131-140.

Jin, J.C., \& Yu, E.S.H. (1996). Export-led Growth and the US economy: another look. Applied Economics Letters, $3(5), 341-344$.

Johansen, S. (1988). Statistical Analysis of Cointegration Vectors. Journal of Economic Dynamics and Control, 12, 231-254.

Johansen, S., \& Juselius, K. (1990). Maximum Likelihood Estimation and Inference on Cointegration with Applications to the Demand for Money. Oxford Bulletin of Economics and Statistics, 52, 169-210.

Jung, W.S., \& Marshall, P.J. (1985). Exports, Growth and Causality in Developing Countries. Journal of Development Economics, 18(1), 1-12.

Kamin, S. (2007). Estimation of De Facto exchange rate regimes: Synthesis of the techniques for inferring flexibility and basket weights. 8th Jacques Polak Annual Research Conference. November 15-16, 2007. 
Kavoussi, R.M. (1984). Export Expansion and Economic Growth: Further Empirical Evidence. Journal of Development Economics, 14, 241-250.

Keho, Y. (2017). The Exports and Economic Growth Nexus in Cote D'ivoire: Evidence from a Multivariate Time Series Analysis. Asian Journal of Economic Modelling, 5(2), 135-146.

Khan, A.H., \& Saqib, N. (1993). Exports and Economic Growth: The Pakistan Experience. International Economic Journal, 7(3), 53-64.

Kovocic, Z.I., \& Djukic, D. (1990). Export Expansion and Economic Growth in Yugoslavia: Some Empirical Evidence. Economic Analysis and Worker's Management, 15(2), 95-113.

Kravis, I.B. (1970). Trade as a Handmade of Growth.Similarities between the Nineteenth and Twentieth Centuries. Economic Journal, 80(320), 850-870.

Kravis, I.B. (1973a). A Reply to Mr. Adams. Economic Journal, 83(329), 212-217.

Kravis, I.B. (1973b). A Reply to Mr.Crafts' Note. Economic Journal, 83(331), 885-889.

Kugler, P. (1991). Growth, Exports and Cointegration: An Empirical Investigation. WeltwirtschafflichesArchiv, 127, $152-174$.

Kugler, P., \& Dridi, J. (1993). Growth and Exports in LDCs: A Multivariate Time Series Study. RevistaInternazionale Di ScienzeEconomiche e Commerciali, 40, 759-767.

Kunst, R.M., \& Martin, D. (1989). On Exports and Productivity: A Causal Analysis. Review of Economics and Statistics, 71, 699-703.

Kwan, A.C.C., Cotsomitis, J.A., \& Kwok, B.K.C. (1999). Exports, Economic Growth and Structural Invariances: Evidence from some Asian NICs. Applied Economics, 31(4), 493-498.

Kwan, A.C.C., \& Kwok, B. (1995). Exogeneity and the Exports-Led Growth Hypothesis: The case of China. Southern Economic Journal, 1158-1166.

Kwan, A.C.C., Cotsomitis, J.A., \& Kwok, B. (1996). Exports, Economic Growth and Exogeneity: Thaiwan 1953-88. Applied Economics, 28, 467-471.

(1999). Exports, Economic Growth and Structural Invariance: Evidence from some Asian NICs. Applied Economics, 31, 493-498.

Lai, C.F. (2018). Fiscal Policy and Macroeconomic Fluctuations in a Fixed Exchange Rate Regime. Asian Economic and Financial Review, 8(10), 1257-1273.

Lee, F.Y., \& Cole, W.E. (1994). Simultaneity in the Study of Exports and Economic Growth. International Economic Journal, 8(1), 33-41.

Levy-Yeyati, E., \& Sturzenegger, F. (2003). To Float or to Fix: Evidence on the Impact of Exchange Rate Regimes on Growth. American Economic Review, 93(4), 1173-1193.

Love, J. (1994). Engines of Growth: The Export and Government Sectors. The World Economy, 17(2), 203-218.

Lukito, R. (2019). The Logic of State Authority on the Control of Agrarian Resource (Socio-Anthropological and Islamic Perspective). American Journal of Social Sciences and Humanities, 4(4), 516-527.

Lussier, M. (1993). Impacts of Exports on Economic performance: A Comparative Study. Journal of African Economies, 2(1), 106-127.

Maneschiold, Per-Ola. (2008). A Note of the Export-Led Growth Hypothesis: A Time Series Approach. Cuadernos De Economia, 45, 293-302.

Marin, D. (1992). Is The Export-led Growth Hypothesis Valid for Industrialized Countries?. Review of Economics and Statistics, 54, 678-688.

McKinnon, R., \& Schnabl, G. (2003). The East Asian Dollar Standard, Fear of Floating, and Original Sin. Macroeconomic Stability, Financial Markets, and Economic Development, Bank of Mexico.

Michaely, M. (1977). Export and Growth: An Empirical Investigation. Journal of Development Economics, 4(1), 49-53.

Moschos, D. (1989). Export Expansion and the Level of Economic Development: An Empirical Analysis. Journal of Development Economics, 30(1), 93-102. 
Ng, T.H. (2006). Foreign Direct Investment and Productivity: Evidence from the East Asian Economics. United Nations Industrial Development Organization. Research and Statistics Branch.Working Paper No.3.

Nilsson, K., \& Nilsson, L. (2000). Exchange Rate Regimes and Export Performance of developing Countries. Blackwell Publishers, pp.331-349.

Osterwald-Lenum, M. (1992). A Note with Quartiles of Asymptotic Distribution of the Maximum Likelihood Cointegration Rank Test Statistics. Oxford Bulletin of Economics and Statistics, 53, 461-472.

Oxley, L. (1993). Cointegration, Causality and Export-led Growth in Portugal, 1965-1985. Economics Letters, 43, 163-166.

Petreski, M. (2009). Exchange rate Regime and Economic Growth: A Review of the Theoretical and Empirical Literature. Open-Assessment E-Journal, No.2009-31.

Ram, R. (1985). Exports and Economic Growth: Some Additional Evidence. Economic Development and Cultural Change, 33(2), 415-425.

Ram, R. (1987). Exports and Economic Growth in Developing Countries: Evidence from Time Series and Cross-Section Data. Economic Development and Cultural Change, 35(1), 51-63.

Rambeli, N. (2004). Dynamic Relationship between Money, Output and Exchange Rate in Two Exchange Rate Regime. Unpublished article.

Rambeli, N., \& Podivinsky, J. (2013). A Study of Exogeneity Tests on Export-Led Growth Hypothesis: The Empirical Evidences on Post-Crisis Exchange Rate Regime in Malaysia. International Business Education Journal, 6(1), 7-20.

Rambeli, N., Dayang-Affizzah, A.M., \& Hashim, E. (2016). The Effect of Foreign Direct Investment, Export and Employment on Economic Growth. International Journal of Academic Research in Business and Social Science, 6(11), 459-376.

Rambeli, N., Hashim, E., Hashim, A., Dayang Affizah, A.M., \& Podivinsky, J.M. (2017). Empirical analysis on exchange rate fluctuation and sectoral stock returns in Malaysia. Jurnal Ekonomi Malaysia, 51(1), 33-40.

Rambeli, N., Podivinsky, J., \& Jalil, N. A. (2019). The Re-examination of the Dynamic Relationship between Money, Output and Economic Growth in Malaysia. International Journal of Innovation, Creativity and Change, 5(2), 1812-1834.

Rambeli, N., Podivinsky, J., Hashim, A., \& Hashim, E. (2014). Issues On Exchange Rate Volatility \& Exports Nexus - "A Case for Asean". Management Research Journal, 3(2014), 164-184. Retrieved from https://docs.wixstatic.com/ugd/7b8359_d4c26c246ac84c22ae1179729d6a6fa1.pdf

Riezman, R.G., Summers, P.M., \& Whiteman, C.H. (1996). The Engine of Growth or its Handmaiden? A Time Series Assessment of Export-Led Growth. Empirical Economics, 21, 77-113.

Rauf, A. L. A. (2016). Financial management practices in small and medium sized enterprises: Empirical evidence from the district of Ampara in Sri Lanka. International Journal of Economics, Business and Management Studies, 3(3), 117-126.

Salvatore, D., \& Hatcher, T. (1991). Inward and Outward Oriented Trade Stategies. Journal of Development Studies, $27,7-25$.

Sasongko, G., Huruta, A.D., \& Wardani, A. (2019). Does the Wagner's Law exist in a strategic national area? An evidence from Kedungsepur - Indonesia. Insights into Regional Development, 1(2), 99-117.

Sengupta, J.K. (1991). Rapid Growth in NICs in Asia: Tests of New Growth Theory for Korea. Kyklos, 44(4), 561-579.

Sengupta, J.K., \& Espana, J.R. (1994). Exports and Economic Growth in Asian NICs: An Econometric Analysis of Korea. Applied Economics, 26(1), 41-51.

Serletis, A. (1992). Export Growth and Canadian Economic Development. Journal of Development Economics, 38(1), 133-145.

Serven, A.K. (1968). The Relation of Exports and Economic Growth: Comment. Kyklos, 21(3), 546-548.

Shan, J., \& Sun, F. (1998a). Export-Led Growth Hypothesis for Australia: An Empirical Re-Investigation. Applied Economics Letters, 5, 423-428. 
Shan, J., \& Sun, F. (1998b). On the Export-Led Growth Hypothesis: The Econometric Evidence from China. Applied Economics, 30, 1055-1065.

Sharma, S.C., Norris, M., \& Cheung, D.W.W. (1991). Exports and Economic Growth in Industrialized Countries. Applied Economics, 23, 697-708.

Sheehey, E.J. (1993). Exports as a factor of Production: A Consistency Test. World Development, 21(1), 155-160.

Sims, C. A. (1972). Money, Income, and Causality. American Economic, 62, 540-552.

Sims, C.A., Stock, J.H., \& Watson, M.W. (1990). Inference in Linear Time Series Models with Unit Roots. Econometrica, 58, 113-144.

Suliman, O.T., Mengistu, R., Lorente, R., \& Ghebreyesus, G.S. (1994). Export Growth and Industrial Development: Evidence from South Korea. Economia Internazionale, XLVII(1), 84-91.

Syron, R.F., \& Walsh, B.M. (1968). The Relation of Exports and Economic Growth: A Note. Kyklos, 20(3), 541-545.

Thornton, J. (1997). Exports and Growth: Evidence from 19th Century Europe. Economic Letters, 55, 235-240.

Tiwari, R. (2003). Post-Crisis Exchange Rate Regimes in Southeast ASIA: An Empirical Survey of De-Facto Policies. Working Paper (University of Hamburg).

Todo, H.Y., \& Phillips, P.C.B. (1993). Vector Autoregressions and Causality. Econometrica, 61, 1367-1393.

Todo, H.Y., \& Phillips, P.C.B. (1994). Vector autoregression and causality: A theoretical overview and simulation study. Econometrics Review, 13(2), 259-285.

Tyler, W.G. (1981). Growth and Export Expansion in Developing Countries: Some Empirical Evidence. Journal of Development Economics, 9(1), 121-130.

Ukpolo, V. (1994). Export Composition and Growth of Selected Low-Income African countries: Evidence from Time Series Data. Applied Economics, 26(5), 445-449.

Vahid, F., \& Engle, R.F. (1993). Common Trends and Common Cycles. Journal of Applied Econometrics, 8, 341-360.

Van den Berg, H., \& Schmidt, J.R. (1994). Foreign Trade and Economic Growth: Time Series Evidence from Latin America. Journal of International Trade and Economic Development, 3(3), 121-130.

Wang, H., Peng, G., \& Lv, B. (2018). Effect of Retail Investor Attention on Chinas A-Share Market Under a Strengthening Financial Regulatory Policy. Asian Economic and Financial Review, 8(10), 1274-1297.

Xu, Z. (1996). On the Causality between Export Growth and GDP Growth: An Empirical Re-investigation. Review of International Economics, 4(2), 172-184.

Yamada, H. (1998). A Note on the Causality between Export and Productivity: An Empirical Re-examination. Economics Letters, 61, 111-114. 


\section{Appendix}

Table 2. The Result of variance for exchange rate, import, export and economic growth

\section{Notes}

\begin{tabular}{ll}
\hline LAG & AIC \\
\hline 2 & -8.904320 \\
\hline 3 & -8.914047 \\
\hline 4 & -8.890960 \\
\hline 5 & -8.961775 \\
\hline 6 & -8.886047 \\
\hline 7 & -8.683478 \\
\hline 8 & -8.558305 \\
\hline 9 & -8.500245 \\
\hline 10 & -8.325305 \\
\hline 11 & -8.282140 \\
\hline
\end{tabular}

* indicates lag order selected by the criterion

AIC: Akaike Information Criterion

\section{Error Correction Term (ECT)}

Table 4. The Results of Error Correction Term (ECT) for Exchange Rate, Import, Export and Economic Growth $(\operatorname{ECT}(-1)=26.35795+1 * \operatorname{ER}(-1)+9.2672088 * \operatorname{EX}(-1)-8.796705 * \operatorname{IMP}(-1)+0.843818 * \operatorname{GDP}(-1))$

\begin{tabular}{lc}
\hline Cointegrating Eq: & CointEq1 \\
\hline \hline ER(-1) & 1.000000 \\
\hline EX(-1) & 21.88155 \\
& $(5.62228)$ \\
& {$[3.89194]$} \\
\hline IMP(-1) & -16.60626 \\
& $(4.80432)$ \\
& {$[-3.45653]$} \\
\hline GDP(-1) & 0.726475 \\
& $(3.38453)$ \\
\hline C & $0.21465]$ \\
\hline
\end{tabular}

